Buyak, B.B., Korsun, I.V., and Matsyuk, V.M.

Ternopil Volodymyr Hnatiuk National Pedagogical University,

2, M. Kryvonos St., Ternopil, 46027, Ukraine, +380352435880,info@tnpu.edu.ua

\title{
CONTRIBUTION OF UKRAINIAN SCIENTISTS TO THE DEVELOPMENT OF TECHNOLOGY
}

\begin{abstract}
Introduction. Today, we can use phrase "the world's first" for many inventions of Ukrainian scientists. Ukraine is a country with a high level of science development. As a proof of this statement, one may take the international recognition of achievements made by Ukrainian scientists in different areas of technology.

Problem Statement. Ukraine aspires to become an equal member of the European Union. It is important that Ukrainians do not lose their national identity in this direction of movement. Disseminating knowledge about Ukrainian scientists is one of the ways to increase Ukraine's recognition in the world. That is why it is necessary to demonstrate to the world community the achievements of Ukrainian scientists and their high scientific level.

Purpose. The research is aimed at justifying importance of Ukrainian scientists' works for the development of technology in the world.

Materials and Methods. The analytical review of the works of Ukrainian scientists that have the great importance for the development of technology in the world, was carried out.

Results. The importance of Ukrainian scientists' works in photography, cinematograph, electric welding, computer technology, aviation, astronomy, rocket science and astronautics has been proved. Ukrainian scientists were among the first in the invention of television, electric tram and radio control. Thanks to the work of our compatriots, it became possible to launch the first artificial satellite of the Earth, to make the flight of man to space, the exit of man in open space and landing on the surface of the Moon.

Conclusions. Priority of Ukrainian scientists' works in many researches testifies to their significant contribution to the development of world technologies. Coverage of this contribution should by no means ignite interethnic animosity, but it can serve as an incentive to realize the national identity of Ukrainians in the context of world integration. The main principle is that science should unite peoples, and be the foundation of peace in the world. Given that Ukraine has significant achievements in science and technology, further research in this area is appropriate.
\end{abstract}

Keywords: Ukrainian scientists, technology, and inventions.

In 1999, the Permanent Delegation of Ukraine to the United Nations Educational, Scientific and Cultural Organization (UNESCO) requested that the Organization should be associated with the celebration of the hundredth anniversary of the birth of O.T. Smakula (1900-1983) [1]. Therefore, at its $157^{\text {th }}$ session, the Executive Board of the Organization decided the UNESCO to join the celebration of the hundredth anniversary of

(C) BUYAK, B.B., KORSUN, I.V., and MATSYUK, V.M., 2019 the birth of Ukrainian physicist, on September 9, 2000. It is well known that O. Smakula of Carl Zeiss $A G$ company (Jena) invented and patented the world's first optical anti-reflective coatings in 1935 [2] without which it is impossible to imagine modern optical technology. "Alexander Smakula challenged the boundaries of accepted optics and made an invention which has improved the life and work of millions of people", says Dr. Heinen, Executive Vice President and General Manager of The Vision Care Business Group at Carl Zeiss AG [3]. 
The contribution of Ukrainian scholars to the development of science in the world was demonstrated in some manuals [4-9], as well as many scientific and methodological papers. Today, we can use phrase "the world's first" for many inventions of Ukrainian scientists. The aim of article is to prove the importance of Ukrainian scientists' works for the development of technology in the world.

\section{PHOTOGRAPHY}

E.A. Kirillov (1883-1964) is a founder of the Odesa scientific school in scientific photography. In 1930, he discovered the phenomenon of negative photoeffect and showed that this phenomenon associated with the process of latent photographic image formation. The Ukrainian scientist developed the theory of the origin of a photographic image $[10,11]$ and fulfilled researches of the phenomena that play an important role for the fabrication of photographic materials.

In 1937-1945, Ukrainian physicist O.O. Stasiw (1903-1985) worked as the head of a laboratory at the Zeiss Icon firm in Dresden (Germany). At that time, there emerged a problem concerning the enhancement of the photographic film sensitivity, and O. Stasiw worked at that problem. In 1938, R. Gurney and N. Mott developed the theory of latent photographic image formation [12]. However, some aspects of this theory (e.g., the structure of capture centers, the types of charge carriers and the mechanisms of their localization, and possible ways to enhance the sensitivity of photographic materials) remained obscure. The corresponding researches were carried out by O. Stasiw and J. Teltow [13]. In this sense, the Stasiw-Teltow model essentially developed and specified the Mott-Gurney theory, which had a considerable value for the perfection of the technology of photographic materials.

\section{CINEMATOGRAPH}

It is generally recognized that French inventors Auguste and Louis Lumière invented a cinematograph. In 1895, the Lumière brothers demonstated the film which is officially considered the world's first motion picture [14].

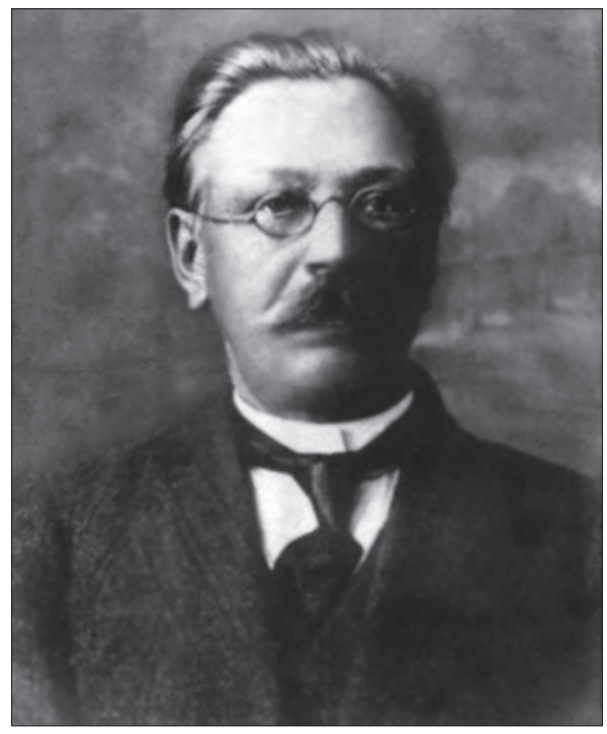

Yosyf Andriiovych Tymchenko

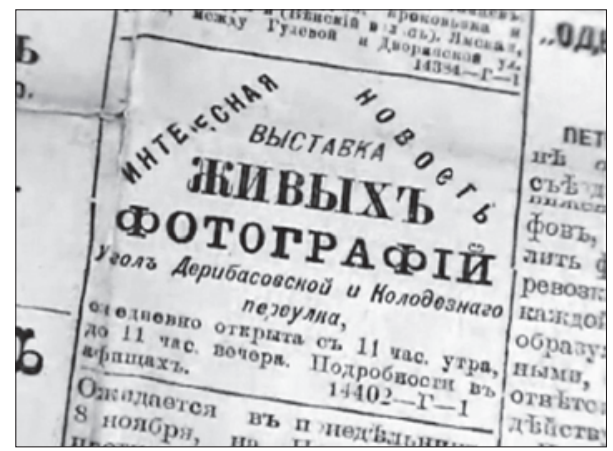

An announcement in the newspaper "Odesskii listok"

(7 November, 1893)

In the Museum of Applied Knowledge (Moscow, Russia) there is an exhibit of the first in the world mechanism for the change of images in the photo [15]. The mechanic of the Imperial Novorossiysk University (Odesa, Ukraine) Y.A. Tymchenko (1852-1924) was an author of the present invention. The first public demonstration of films took place in Odessa on November, 1893. An announcement of Odessa newspaper contained information about the demonstration of films by Y. Tymchenko at the France hotel. On January 9, 1894, Y. Tymchenko demonstrated the first prototype of a cinema camera in Moscow [16]. In this way, Y. Tymchenko is a creator of cinematograph. 


\section{TELEVISION}

Many scientists worked on developing the principles of television. But most scientists used the mechanical method of transmitting impulses. Therefore, the inventors did not get the desired result. For the first time in the world, Ukrainian inventor B.P. Grabovskyi (1901-1966) created an electronic system on wireless transmission of a moving image at distance. In 1921-1923, the scientist developed and constructed an electronic transmitting tube, and then worked on the improvement of TV equipment. In 1928, B. Grabovskyi together with M. Piskunov and V. Popov received a patent on electronic television [17]. On July 26, 1928, B. Grabovskyi and I. Beliansky carried out a practical transfer the moving image for a distance.

\section{ELECTRIC WELDING}

In 1885, Ukrainian scientist M.M. Benardos (1842-1905) received a patent on own method of electric arc welding of metals in a number of European countries (France, Belgium, England, Sweden, and Germany). It was possible to cut metal using the Benardos method. M. Benardos noted the possibility of using the electric welding under the water [18]. For the first time in the world, Ukrainian scientist K.K. Khrenov (1894-1984) experimentally demonstrated the possibility of stable work of the electric arc under the water in 1932. K. Khrenov developed methods of underwater electric welding and cutting metals [19].

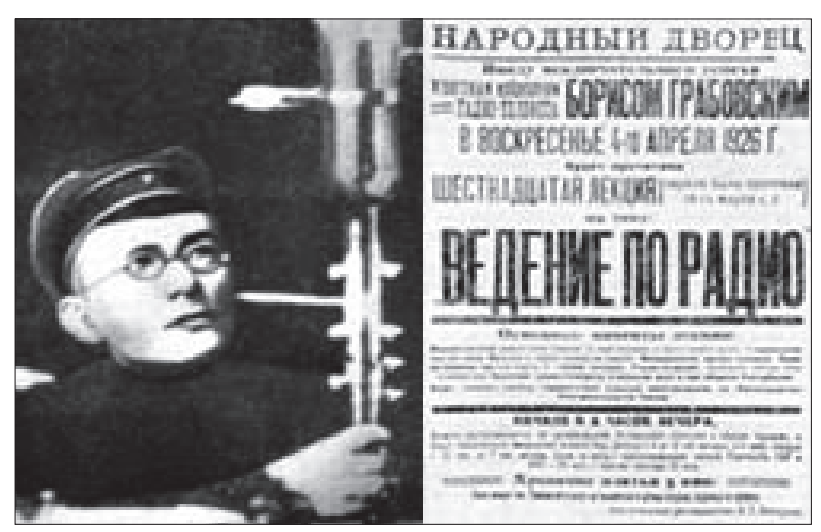

B. P. Grabovskyi with a device for transmitting moving images to a distance (poster on public lection, 1926)



Fedir Apollonovych Pirotskyi

In 1934, Ye.O. Paton (1870-1953) founded Electric Welding Institute that is world famous. Ukrainian scientists led by Ye. Paton developed a method of high-speed welding in 1930-1940 [20]. The method of Ukrainian scientists allowed refusing manual welding. Such technology appeared in the United States only in 1944. P.I. Sevbo (19002001) developed the equipment for the high-speed automatic submerged arc welding of T-34 tank armor [21]. Paton Bridge is the world's first fully welded bridge. The bridge across the Dnipro River (Kyiv, Ukraine) has length at 1543 meters and named after its constructor Ye. Paton.

Ukrainian scientists continue to study the methods of electric welding under the leadership of B.Ye. Paton. B. Paton is an author and co-author of more than 720 inventions (500 foreign patents) and more than 1200 various published works. For the first time in the world, the Ukrainian scientists of the Paton Electric Welding Institute developed special equipment for conducting electric welding in space.

\section{ELECTRIC TRAM}

Ukrainian engineer F.A. Pirotskyi (1845-1898) is an inventor of the world's first electric tram [22]. In 1874, F.A. Pirotskyi conducted a series of experiments, which demonstrated the possibility of transmitting electricity at a distance. The Ukrainian researcher came to the idea of using the existing railways for electricity transmission. 


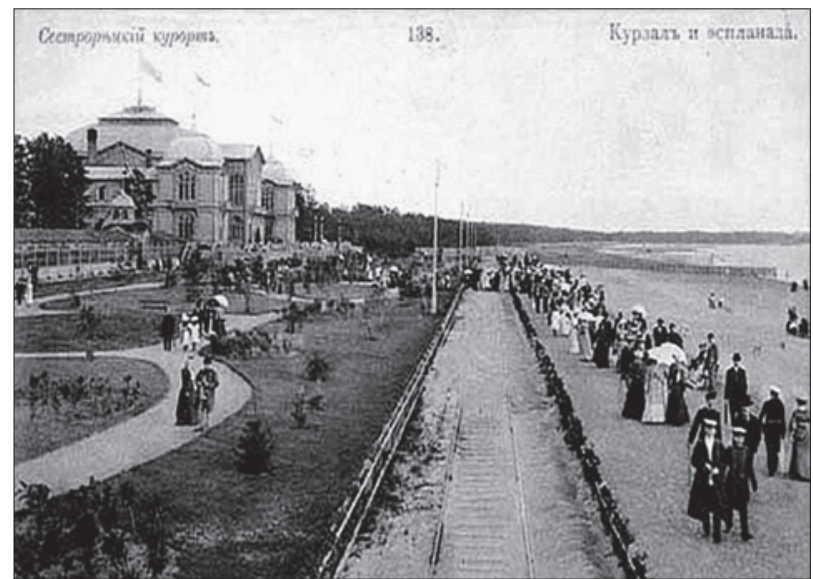

A part of the railway (St. Petersburg) was used as a line of electricity transmission

In 1880, Pirotskyi demonstrated the transmission of electric current along the railways in St. Petersburg (Russian Empire) [23]. The carriage moved along the rails at a voltage of 100 V. F. Pirotskyi did not have money to continue his experiments, and the government of the Russian Empire was not interested in the invention. But the works of Pirotskyi stirred interest around the world. In 1881, the world's first electric tram line was opened in Berlin (Germany). Only in 1892, the first permanent tram line was opened in the Russian Empire (Kyiv).

\section{RADIO CONTROL}

It is known that M.D. Pylchykov (1857-1908) gave a lecture at the Imperial Novorossiysk University (Odessa, Ukraine) on March 23, 1898 [24]. During lecture the Ukrainian scientist demonstrated the work of the clock, semaphore and lighthouse, which were guided by radio waves. For the first time, Serbian inventor N. Tesla publicly demonstrated his radio system only in September 1898, during the First Annual Electrical Exhibition [25]. It was a boat, which sailed in a pool in the great hall of Madison Square Garden (USA). In this way, M. Pylchykov is the first in the world who demonstrated radio control. The Ukrainian inventor also constructed a radioprotector for protect radio transmissions from interception.

\section{COMPUTER TECHNOLOGY}

J.V. Atanasoff, professor of mathematics and physics at Iowa State College (USA), with C.E. Berry, his graduate assistant, completed a successful model of the first electronic digital computer on May, 1942 [26]. The Atanasoff-Berry computer was the world's first electronic computer, named for its inventors. J. Atanasoff used works of Ukrainian mathematician M.P. Kravchuk (1892-1942) when he created the first electronic computer [27].

M. Kravchuk is an author of more than 180 works on mathematics and applied mathematics. In 1937, Atanasoff wrote to the Ukrainian mathematician and Ukrainian Association for Cultural Relations and asked to send him works of M. Kravchuk [28]. J. Atanasoff translated several works of Kravchuk on English, but the translations remained unpublished.

The first computer in continental Europe was created in Ukraine at the Institute of Electrical Engineering of the Academy of Sciences of the UkSSR under the direction of S.O. Lebedev on December 25, 1951. Ukrainian scientists were the third in the world after scientists of USA and Great Britain in creation of electronic computer.

\section{AVIATION}

On September 14, 1939, the Ukrainian constructor I.I. Sikorsky (1889-1972) made the first ex-



The first flight of I. Sikorsky on the prototype VS-300 helicopter (Sikorsky Historical Archives) 
perimental flight on helicopter [29]. The successful flight happened at Stratford, Connecticut (USA), and its duration was 10 seconds. I. Sikorsky demonstrated that the helicopter could be controlled. The prototype VS-300 helicopter had single main rotor and single tail rotor. According to Fox (2005), "no real helicopter production run occurred until Sikorsky started building R-4 helicopters for the US Army Air Corp with first delivery in 1944" [30]. In this way, the helicopter of Sikorsky was the first helicopter, which was made in full-scale production. I. Sikorsky is also an author of the first aircrafts with multiple motors, turbine helicopter, and amphibious helicopter.

Russian aircraft designer O.K. Antonov (19061984) worked in Ukraine during many years. He created about 30 models of gliders. The designer was a known popularizer of aviation [31]. O. Antonov was the first chief of an aircraft company in Ukraine, later named in his honour. Today Antonov State Company is a famous aircraft company in the world. Over 22.000 Antonov aircraft have been built and many of them have been exported to over 50 countries. AN-225 Mriia is the world's largest plane, which rose into the air more than once and has more than 240 world records. It is known that the world's first unmanned space plane Buran was mounted on AN-225 Mriia [32].

\section{ASTRONOMY}

For the first time in the world, Ukrainian astronomer M. P. Barabashov (1894-1971) proved the possibility of landing of man on the Moon. The Ukrainian scientist created own astronomical observatory in Kharkiv. At his astronomical observatory, the scientist investigated the phenomenon of reflection of light by the Moon and showed that the surface of satellite consists of volcanic rock basalt type with a high porosity. M. Barabashov made this discovery in 1918 and published later [33]. Only in the 1960s, after flights to the Moon, the theory of basaltic type of the surface of the satellite was confirmed. M. Barabashov opened the polar caps on Mars, the ice crystals at Venus' atmosphere, photographed the solar coro-

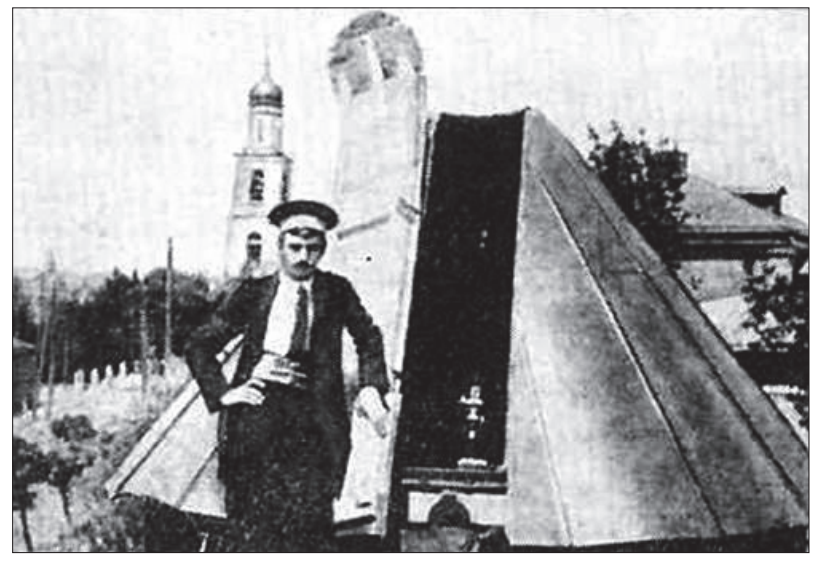

M. Barabashov near home astronomical observatory in Kharkiv

na, and also studied Jupiter and Saturn. Scientist was known as a popularizer of astronomy [34].

Ukrainian astronomer K.I. Churyumov (19372016) popularized the science in our country and abroad. K. Churyumov known thanks to the photographic observations of celestial bodies. The scientist together with employees discovered two comets that are named $67 \mathrm{P} /$ Churyumov-Gerasimenko (1969) and C/1986 N1 Churyumov-Solodovnikov (1986). In 2004, European probe Rosetta with Philae module was launched. In 2014, the Philae module successfully landed on the comet 67P/Churyumov-Gerasimenko. For the first time in history, a spacecraft landing on a comet. Rosetta made several important discoveries [35, 36].

\section{ROCKET SCIENCE}

Ukrainian constructor G.E. Langemak (18981938) introduced the term "cosmonautics", he was a constructor of missile technology [37, 38] and worked with V.P. Glushko (1908-1989) and S.P. Korolov (1906-1966). V. Glushko was an author of first in the USSR rockets engine on liquid fuel. G. Langemak was a main constructor of Katyusha rocket launchers that was successfully used by Soviet Union during World War II.

Russian constructor M.K. Yangel (19111971) has the Ukrainian origin. For the first time in the world, M. Yangel offered the idea of "mortar launch". According to this idea, rocket kept in a large container, which transported. It gave the 
opportunity to launch rocket from any point of the country. Scientists of USA solved this task only after five years.

From 1954, M. Yangel headed Yuzhnoye State Design Office (Dnipro, Ukraine). Scientist was a one of the main constructors of the Satan rocket that is the most powerful intercontinental rocket in the world. This rocket was created in Yuzhnoye State Design Office. M. Yangel was an author of Zenit rocket, which is used in Sea Launch program. Environmentally friendly space Zenit rocket has a completely automated process of preparation and start-up. This provides highly accurate output spacecraft to orbit.

Today, Yangel Yuzhnoye State Design Office is a world leader in the use of military strategic rockets for space carriers. There are 876 successful launches of rockets at this moment [39]. On 18 October, 2016, in Virginia (USA) the successful launch of Antares OA5 rocket has been held. Yangel Yuzhnoye State Design Office and other Ukrainian companies took part in the creation of the first stage of this rocket [40].

\section{ASTRONAUTICS}

Yu.V. Kondratiuk, real name is O.G. Shargei, (1897-1942) is an author of the first known Lunar Orbit Rendezvous. Scientist created a concept of landing spacecraft on the Moon. His basic ideas on astronautics were published in 1929 [41]. Ukrainian scientist explained how to slow the spacecraft during landing, gave the basic equations of motion missiles, explored the structure of the jet engine and fuels for him, suggested using the gyroscope for orientation of spacecraft. American scientists developed an Apollo program, based on the ideas of Yu. Kondratiuk [42]. American scientist of Ukrainian origin I.D. Bogachevs- ky (1928-2010) realized the ideas of Yu. Kondratiuk and created the theory of the return of a spacecraft to an orbital station from the surface of another planet. This made it possible to return to Earth a spacecraft in the Apollo program. The landing of man on Moon was successfully completed on July 21, 1969.

It is known that first intercontinental ballistic missile was launched on 21 August, 1957; the first artificial Earth satellite was launched on October 4, 1957; Yu.A. Gagarin made the first flight to space on April 12, 1961; A.A. Leonov made the first exit in open space on March 18, 1965. The Ukrainian constructor S.P. Korolov managed all these projects [43].

According to L.K. Kadeniuk (1951-2018), the first astronaut of independent Ukraine, "Ukraine is among of six states in the world, which have the complete cycle of space technology production..." [44]. In this sense, we can note that "studies estimate a USD 7-14 return on investment for every $\$ 1$ of NASA expenditure" [45].

In our study, a small number of works has been analyzed. But we may draw conclusion about a considerable contribution of Ukrainian scientists to the creation of technology in the world. In particular, the invention of cinematograph, television, electric tram, electric welding and radio control, the creation of the first helicopters and the world's largest transport aircraft, the launch of first Sputnik, the first flight of man to space, the first exit of man in open space, the landing of first man on Moon were made thanks to the work of Ukrainian scientists.

Acknowledgments. The authors of this article are thankful to anonymous reviewer for important comments.

\section{REFERENCES}

1. Proposals by member states concerning the celebration of anniversaries with which UNESCO could be associated in 2000-2001. Hundred and fifty-seventh Session, 4 October, 1999, Paris. URL: http://unesdoc.unesco.org/images/0011/ 001174/117410E.pdf (Last accessed: 05.10.2018).

2. German Patent DE 685767 (1 November, 1935). A. Smakula. Verfahren zur Erhöhung der Lichtdurchlässigkeit optischer Teile durch Erniedrigung des Brechungsexponenten an den Grenzflächen dieser optischen Teile [in Germany]. 
3. Walmart opens new Coating Center of Excellence at Fayetteville (12 May, 2015). URL: https://www.zeiss.com/ vision-care/int/about-us/news/press-releases/walmart-opens-new-coating-center-of-excellence-at-fayetteville.html (Last accessed: 06.10.2018).

4. Romanchuk, O. K. (Ed.). (1991). Axioms for Posterity: Ukrainian Names in the World Science. Lviv: Kameniar [in Ukrainian].

5. Romanchuk, O. K. (Ed.). (1992). Axioms for Posterity: Ukrainian Names in the World Science. Lviv: Memorial [in Ukrainian].

6. Andrianov, B. M. (1995). Essays on the History of Physics Development in Ukraine. Vinnytsia: VDPI [in Ukrainian].

7. Golovko, M. V. (1998). Application of Materials on the History of Domestic Science while Studying Physics and Astronomy. Kyiv: "International financial agency" Ltd [in Ukrainian].

8. Khramov, Yu. A. (1991). History of Formation and Development of Physical Schools in Ukraine. Kyiv: Feniks (in Russian).

9. Shenderovskyi, V. A. (2009). Let the Light of Science Not Die Away. Kyiv: Prostir Publ. House [in Ukrainian].

10. Kirillov, E. A. (1911). On the anomalous dispersion in Lipman color photographs. Zhurnal Russkogo fiziko-khimicheskogo obshchestva, 43(8), 405-422 [in Russian].

11. Kirillov, E. A. (1925). On the electrical conductivity of the latent image. Zhurnal Russkogo fiziko-khimicheskogo obshchestva, 57(3/4), 259-266 [in Russian].

12. Gurney, R. W., \& Mott, N. F. (1938). The Theory of the Photolysis of Silver Bromide and the Photographic Latent Image. Proc. R. Soc. Lond. A, 164, 151-167. doi: 10.1098/rspa.1938.0011.

13. Dovhyj, O. (2002). The Stasiw-Teltow's model in classical photographic theory. Ukr.J. Phys., 47(11), 1099-1103.

14. Augustyn, A., Bauer, P., Duignan, B., Eldridge, A., Gregersen, E., McKenna, A., ... Zelazko, A. (2014). Lumière brothers. Encyclopaedia Britannica. URL: https://www.britannica.com/biography/Lumiere-brothers (Last accessed: 13.10.2018).

15. Mislavskii, V., \& Gergesha, V. (2012). Mechanic inventor Yosyf Tymchenko in documents and memoirs. Kharkov: Vydavnychyi budynok "Faktor" [in Russian].

16. Diary of the IX-th Congress of Russian naturalists and doctors, 11 January, 1894, Moscow [in Russian].

17. Patent on invention №5592, type 21a1, 32 (30 June, 1928, Leningrad). Description of the apparatus for electrical telescopes to the patent of V. I. Popov, B. P. Grabovskyi and N. G. Piskunov, declared 9 November, 1925 (certificate on application № 4899) [in Russian].

18. Matiiko, M. M., \& Inozemtsev, S. I. (1952). The contribution of domestic scientists in the science on electricity. Kyiv: Radianska shkola [in Ukrainian].

19. Khrenov, K. K. (1946). The underwater electric welding and cutting metals. Moscow: Voennoe izdatelstvo Ministerstva VS USSR [in Russian].

20. Paton, Ye. O. (1941). High-speed automatic welding under the flux layer. Moscow: Mashgiz [in Russian].

21. Makovetska, O. K. (2018). Development of technology and equipment for high-speed arc welding under the flux.

The National Academy of Science of Ukraine. Outstanding achievements. 1918-2018. Kyiv: Fenix [in Ukrainian].

22. Rzhonsnytskyi, B. N. (1951). F. A. Pirotskyi. The inventor of the electric tram. Kyiv: Derzhtekhvydav Ukrainy [in Ukrainian].

23. Pyrgidis, C. N. (2016). Raikway Transportation Systems: Design, Construction and Operation. Oakville: Apple Academic Press.

24. Poliakova, N. L., \& Popova-Kiandskaia, E. A. (1954). Nikolai Dmitrievich Pylchykov. Uspekhi Fizicheskikh Nauk, 53, 121-136. doi: 10.3367/UFNr.0053.195405f.0121 [in Russian].

25. Marincic, A., \& Budimir, D. (2008). Tesla's Multi-frequency Wireless Radio Controlled Vessel. In: IEEE Conference on History of Telecommunications (HISTELCON 2008), 11-12 September, 2008, Paris, France, 24-27.

26. Ralston, A., Reilly, E. D., \& Hemmendinger, D. (2003). Encyclopedia of Computer Science. Chichester: John Wiley and Sons Ltd.

27. Katchanovski, I. (2004). A Puzzle in the Invention and Patenting of the Electronic Computer in the US. In book Development of the Mathematical Ideas of Mykhailo Kravchuk (Krawtchouk), 655-687. Kyiv, New York: National Technical University of Ukraine and Shevchenko Scientific Society in the US.

28. Parasyuk, O., \& Virchenko, N. (2009). Brief survey of the mathematical legacy of academician M. Kravchuk. Fractional Calculus and Applied Analysis, 12(2), 115-134.

29. Swopes, B. R. (14 September, 2018). 14 September 1939. This Day in Aviation. URL: https://www.thisdayinaviation. com/14-september-1939/ (Last accessed: 21.10.2018).

30. Fox, R. G. (2005). The history of helicopter safety. Presented at the International Helicopter Safety Symposium, 26-29 September, 2005, Montréal, Québec, Canada,1. URL: https://www.h-a-c.ca/IHSS_Helicopter_Safety_History_05.pdf (Last accessed: 22.10.2018). 
31. Antonov, O. K. (1990). Gliders. Aircraft. Executive Editor B. E. Paton. Kyiv: Naukova dumka [in Russian].

32. Skorodelov, V. A. From SPIRAL to MAKS. URL: http://www.buran-energia.com/documentation/documentationakc-maks-d.php (Last accesed: 23.10.2018).

33. Barabashov, N. P. (1928). About the composition of the Moon's surface. Visnyk prurodoznavstva, 3-4, 1-4 [in Ukrainian].

34. Barabashov, N. P. (1925). Comets and meteors. Kharkiv: Chervonyi shliakh [in Ukrainian].

35. Altwegg, K., Balsiger, H., Bar-Nun, A., Berthelier, J. J., Bieler, A., Bochsler, P., ... Wurz, P. (2015). 67P/ChuryumovGerasimenko, a Jupiter family comet with a high D/H ratio. Science, 347(6220), 1261952-1261952. doi: 10.1126/ science.1261952.

36. Rubin, M., Altwegg, K., Balsiger, H., Bar-Nun, A., Berthelier, J. J., Bieler, A., ... Wurz, P. (2015). Molecular nitrogen in comet 67P/Churyumov-Gerasimenko indicates a low formation temperature. Science, 348(6231), 232-235. doi: 10.1126/ science.aaa6100.

37. Langemak, G. E. (1934). Projectiles, traction missiles. Design of reactive missiles and traction missiles. Leningrad [in Russian].

38. Langemak, G. E., Glushko, V. P. (1935). Missiles, their construction and using. Moscow, Leningrad: Glavhaia redaktsia aviatsonnoi literatury [in Russian].

39. Yuzhnoye Design Office. URL: http://www.yuzhnoye.com/en/home/ (Last accessed: 04.11.2018).

40. The successful launch of the carrier rocket "Antares". URL: http://www.yuzhmash.com/presscenter/news/ new?id=252\# (Last accessed: 04.11.2018).

41. Kondratiuk, Yu. (1929). Conquest of interplanetary space. Novosibirsk [in Russian].

42. Harvey, B. (2007). Russian Planetary Exploration: History, Development, Legacy and Prospects. Chichester: Springer Praxis Publishing.

43. West, J. B. (2001). Historical aspects of the early Soviet/Russian manned space program. Journal of Applied Physio$\log y, 91,1501-1511$.

44. Kadeniuk, L. (11 March, 2011). Ukraine may lose the status of space state. URL: http://www.bbc.com/ukrainian/ news/2011/03/110311_kadenyuk_shuttle_ak.shtml (Last accesed: 21.10.2018) (in Ukrainian).

45. Lyons, L. (9 September, 2013). 5 Popular Misconceptions about NASA. URL: https://www.huffingtonpost.com/ lauren-lyons/misconceptions-nasa_b_3561205.html (Last accessed: 10.11.2018).

Стаття надійшла до редакціi / Received 28.11.18

Статтю прорецензовано / Revised 20.02.19

Статтю підписано до друку / Accepted 10.04.19

\author{
Б.Б. Буяк, І.В. Корсун, В.М. Мацюк \\ Тернопільський національний педагогічний університет \\ імені Володимира Гнатюка, \\ вул. М. Кривоноса, 2, Тернопіль, 46027, Україна, \\ +380352435880,info@tnpu.edu.ua
}

\title{
ВНЕСОК УКРАЇНСЬКИХ ВЧЕНИХ У РОЗВИТОК ТЕХНІКИ
}

Вступ. Сьогодні фразу «найперший у світі» можна застосувати для чималої кількості винаходів українських вчених. Україна $є$ країною з високим рівнем розвитку науки, а доказом цього твердження є внесок українських науковців у різні галузі техніки.

Проблематика. Україна прагне стати рівноправним членом Європейського Союзу. Важливо, щоб українці не втратили свою національну ідентичність при такому напрямку руху. Одним з шляхів підвищення впізнаваності України у світі є поширення знань про українських вчених через демонстрування світовій спільноті досягнень українських науковців та їх високого наукового рівня.

Мета. Висвітлення важливості робіт українських науковців для розвитку техніки у світі.

Матеріали й методи. Аналітичний огляд низки наукових робіт в галузі техніки.

Результати. Досліджено внесок українських вчених у розвиток техніки у світі та проведено класифікацію відповідно до галузей. Показано важливість робіт українських науковців для розвитку фотографії, кінематографу, електричного зварювання, комп’ютерних технологій, авіації, астрономії, ракетної техніки та космонавтики. Українські вчені були серед перших у винаході телебачення, електричного трамваю та дистанційного керування об'єктами. Завдяки роботам наших співвітчизників став можливим запуск першого штучного супутника Землі, політ людини у космос, вихід людини у відкритий космос та приземлення на поверхню Місяця.

ISSN 1815-2066. Nauka innov., 2019, 15(6) 
Висновки. Пріоритетність робіт українських вчених у ряді досліджень свідчить про вагомий їх внесок у розвиток світових технологій. Висвітлення даного внеску в жодному разі не повинно розпалювати міжнаціональну ворожнечу, проте може слугувати стимулом для усвідомлення власної національної ідентичності українців в умовах світової інтеграції. При цьому, головним принципом є те, що наука має об'єднувати народи і бути фундаментом миру у світі. Зважаючи на те, що Україна має вагомі досягнення у науці й техніці, доцільними є подальші дослідження у зазначеному напрямку.

Ключові слова: українські вчені, техніка, винаходи.

\section{Б.Б. Буяк, И.В. Корсун, В.М. Мачюк}

Тернопольский национальный педагогический университет имени Владимира Гнатюка,

ул. М. Кривоноса, 2, Тернополь, 46027, Украина, +380352435880, info@tnpu.edu.ua

\section{ВКЛАД УКРАИНСКИХ УЧЕНЫХ В РАЗВИТИЕ ТЕХНИКИ}

Введение. Сегодня фразу «первый в мире» можно использовать для многих изобретений украинских ученых. Украина является страной с высоким уровнем развития науки. Доказательством этого утверждения является вклад украинских ученых в различные отрасли техники.

Проблематика. Украина стремится стать равноправным членом Европейского Союза. Важно, чтобы украинцы не утратили свою национальную идентичность при этом направлении движения. Распространение знаний об украинских ученых является одним из путей повышения узнаваемости Украины в мире. Поэтому необходимо демонстрировать мировому сообществу достижения украинских ученых и их высокий научный уровень.

Цель. Обоснование важности работ украинских ученых для развития техники в мире.

Материалы и методы. Аналитический обзор ряда научных работ в области техники.

Результаты. Доказана важность работ украинских ученых для развития фотографии, кинематографа, электрической сварки, компьютерных технологий, авиации, астрономии, ракетной техники и космонавтики. Украинские ученые были среди первых в изобретении телевидения, электрического трамвая и дистанционного управления объектами. Благодаря работам наших соотечественников стал возможным запуск первого искусственного спутника Земли, полет человека в космос, выход человека в открытый космос и приземления на поверхность Луны.

Выводы. Приоритетность работ украинских ученых в ряде исследований свидетельствует о весомом их вкладе в развитие мировых технологий. Освещение этого вклада ни в коем случае не должно разжигать межнациональную рознь, однако может служить стимулом для осознания собственной национальной идентичности украинцев в условиях мировой интеграции. Главным принципом является то, что наука должна объединять народы и быть фундаментом мира. Украина имеет весомые достижения в науке и технике, а поэтому целесообразно проводить дальнейшие исследования в указанном направлении.

Ключевые слова: украинские ученые, техника, изобретения. 